\title{
Fermentasi Limbah Jagung dan Pengaruhnya terhadap Pertumbuhan Jagung Ungu Introduksi di Madura
}

\section{(Fermentation of Corn Waste and Its Effect on Growth of Introduction Purple Corn in Madura)}

\author{
Syaiful Khoiri ${ }^{1}$, dan Mu'alim $^{2}$ \\ ${ }^{1}$ Program Studi Agroekoteknologi, Fakultas Pertanian, Universitas Trunojoyo Madura \\ ${ }^{2}$ Program Studi Teknik Industri, Fakultas Teknik, Universitas Trunojoyo Madura \\ *Email korespondensi: syaiful.khoiri@trunojoyo.ac.id
}

Diterima 26 Februari 2019/Disetujui 01 Maret 2019

\begin{abstract}
The Increassing program in national corn production has been achieved by the government through special efforts over the past 2 years (2016-2017). This success is marked by the closure of import faucets in 2017. Furthermore, government policies are directed at the development of functional corn or corn which has bioactive content that is beneficial to human health. Madura Island has a vast area of corn plantations. This study aims to study the introduction of purple corn by adding organic fertilizer from corn waste in Madura. The research was conducted in the Field Laboratory of Agroecotechnology, Faculty of Agriculture and Manufacturing System Laboratory of the Faculty of Engineering, University of Trunojoyo Madura (UTM). The method of testing is done by application 3 days before planting. Parameters of observation in the field include: characteristic bio-compost, seed germination, plant height, chlorophyll content, and crop production weight. The results of this study indicated that fermented organic fertilizer from corn waste determined the growth and development of plants, and the chlorophyll content of purple corn. The best treatment showed by S1 treatment, with the highest germination and growth response, high chlorophyll content, short flowering age, and has the highest cob and seed weight compared to others treatment.
\end{abstract}

Keywords: compost, organic fertilizer, Zea mays

\section{ABSTRAK}

Peningkatan produksi jagung nasional telah dicapai pemerintah melalui upaya khusus selama 2 tahun terakhir (20162017). Keberhasilan ini ditandai dengan ditutupnya kran impor pada tahun 2017. Selanjutnya, kebijakan pemerintah diarahkan pada pengembangan jagung fungsional atau jagung yang mempunyai kandungan bioaktif yang bermanfaat bagi kesehatan manusia. Pulau Madura mempunyai luasan areal pertanaman jagung yang sangat luas. Penelitian ini bertujuan untuk mempelajari adaptasi jagung ungu introduksi dengan menambahkan pupuk organik dari limbah jagung di Madura. Penelitian dilaksanakan di Kebun Percobaan dan Laboratorium Sistem Manufaktur Fakultas Teknik Universitas Trunojoyo Madura. Metode pengujian yang dilakukan dengan cara aplikasi 3 hari sebelum tanam. Parameter pengamatan di lapangan meliputi: karakteristik bio-kompos, daya kecambah benih, tinggi tanaman, kandungan klorofil, dan bobot produksi pertanaman. Hasil penelitian menunjukkan bahwa pupuk organik hasil fermentasi dari limbah jagung berpengaruh terhadap pertumbuhan dan perkembangan tanaman, serta kandungan klorofil tanaman jagung ungu. Perlakuan terbaik ditunjukkan oleh perlakuan S1 yang menunjukkan respon perkecambahan dan pertumbuhan paling tinggi, kandungan klorofil tinggi, umur berbunga pendek, serta memiliki bobot tongkol dan biji tertinggi dibandingkan dengan perlakuan yang lain.

Kata kunci: kompos, pupuk organik, Zea mays

\section{PENDAHULUAN}

Jagung merupakan salah satu komoditas utama yang menjadi perhatian Pemerintah. Kementrian Pertanian telah melakukan berbagai upaya dalam peningkatan produksi selama 2 tahun terakhir dan menghasilkan capaian yang menggembirakan. Berdasarkan data tahun 2016, produksi jagung Indonesia sekitar 23.58 juta ton atau meningkat 20.22\% dari produksi tahun 2015 sebesar 19.61 juta ton. Data Perkiraan produksi tahun 2017 kembali meningkat $10.39 \%$ menjadi 26.03 juta ton (BPS, 2016). Pada Tahun
2017, Indonesia menutup kran impor karena kebutuhan jagung di Indonesia sudah terpenuhi.

Arah kebijakan pengembangan jagung selain untuk meningkatkan produksi juga diarahkan pada pengembangan jagung fungsional. Jagung fungsional adalah jagung yang mengandung komponen bioaktif yang memberikan efek fisiologis multifungsi bagi tubuh, antara lain memperkuat daya tahan tubuh, mengatur ritme kondisi fisik, memperlambat penuaan dan membantu mencegah penyakit (Suarni dan Subagio, 2013). Jagung Ungu merupakan jagung fungsional yang mengandung antosianin, di mana 
antosianin bersifat antioksidan di dalam tubuh untuk mencegah terjadinya aterosklorosis dan penyakit penyumbatan pembuluh darah (Yasin dan Suarni, 2015).

Produksi jagung fungsional yang diarahkan untuk kesehatan, harus ditunjang dengan penggunaan sarana produksi pertanian yang bebas dari bahan kimia yang berbahaya seperti pestisida dan pupuk an-organik. Pemanfaatan limbah jagung akan mengatasi permasalahan tidak dimanfaatkannya limbah jagung dalam skala besar di Madura. Luas Areal penanaman jagung di Madura sangat luas yakni 301,725 hektar atau 30\% luas areal jagung di Jawa Timur (BPS, 2015). Hal ini memberikan dampak besarnya jumlah limbah jagung di Madura. Tersedianya limbah jagung yang melimpah menjadi tantangan sekaligus peluang untuk dimanfaatkan sebagai bahan pupuk organik dan pakan (Tangendjaya dan Wina, 2007). Pemanfaatan limbah jagung yang meliputi batang, tongkol, dan klobot untuk dijadikan pupuk menggunakan teknik fermentasi yang sesuai dalam produksi jagung fungsional perlu dilakukan dengan tepat.

Berdasarkan latar belakang di atas, diperlukan penelitian tentang fermentasi limbah jagung dan penggunaannya dalam adaptasi jagung ungu di Madura. Penelitian dengan objek tanaman jagung ungu di Madura merupakan yang pertama dilakukan. Tujuan penelitian ini untuk melihat sifat hasil fermentasi limbah jagung dan pengaruhnya terhadap adaptasi, pertumbuhan, dan perkembangan tanaman jagung ungu.

\section{BAHAN DAN METODE}

\section{Penyiapan Bahan Fermentasi dari Limbah Jagung}

Limbah organik pertanian (brangkasan jagung) diambil dari sisa-sisa serasah tanaman jagung di lapangan kemudian dilakukan pencacahan. Pencacahan dilakukan menggunakan pisau pencacah dengan ukuran partikel yang berbeda-beda sebagai faktor pengujian. Ukuran partikel cacahan yang diuji yaitu $<2.5 \mathrm{~cm}$ (S1), 2.5-5 cm (S2), 5-7.5 $\mathrm{cm}$ (S3), dan 7.5-10 cm (S4).

\section{Fermentasi Bahan Organik Limbah Jagung}

Setiap limbah jagung yang telah dicacah sesuai ukuran cacahan yang telah ditentukan, selanjutnya difermentasi mengikuti metode Solid-State Fermentation (SSF) yang dikemukakan oleh Lim dan Matu (2015) dengan sedikit modifikasi. Metode SSF dilakukan dengan cara menambahkan 1 L $10 \%$ konsorsium mikroba fermentatif pada $5 \mathrm{~kg}$ cacahan brangkasan jagung di dalam tangki fermentasi kapasitas 25 liter dengan kondisi tanpa atau sedikit air (1\% air/cacahan). Selanjutnya setiap bahan di fermentasi selama tiga minggu dan dilakukan karakterisasi. Karakter pengamatan yan dilakukan terhadap hasil fermentasi meliputi suhu, kelembaban, kadar air, warna, dan aroma

\section{Pengujian Pupuk Organik terhadap Pertumbuhan dan Produksi Jagung Ungu}

Perlakuan pupuk organik. Lahan dibersihkan dari gulma kemudian diolah hingga gembur. Lahan dibuat guludan untuk memudahkan perlakuan. Pupuk organik hasil fermentasi brangkasan jagung kemudian ditambahkan di lahan dengan dosis 10 ton/Ha. Aplikasi dilakukan sebanyak 1 kali pada 3 hari sebelum tanam.

Daya kecambah benih. Daya kecambah benih dilakukan pada saat 7 hst. Persentase daya kecambah benih dihitung dengan menggunakan rumus:

Daya kecambah beni $=\frac{J m l \text { benih yang tumbuh }}{J m l \text { benih yang ditanam }} \times 100 \%$

Kandungan klorofil daun. Kandungan klorofil daun diukur dengan mengukur kandungan klorofil. Pengamatan dilakukan pada saat tanaman jagung berumur 50 hst.

Pertumbuhan tanaman. Pengamatan pertumbuhan tanaman jagung dilakukan dengan cara mengukur tinggi tanaman. Pengukuran tinggi tanaman dilakukan pada 14 hst, 28 hst, 42 hst. 56 hst, 70 hst, dan 84 hst.

Produksi tanaman. Pengamatan terhadap produksi tanaman meliputi umur berbunga, ukuran tongkol, bobot tongkol, dan bobot per 1000 biji.

\section{Rancangan percobaan dan Analisis data}

Rancangan percobaan yang digunakan adalah rancangan acak lengkap (RAL). Data yang diperoleh dianalisis menggunakan sidik ragam (ANOVA) menggunakan program Microsoft Office Excel 2013 dan SPSS versi 20.0 (Statistical Package for Social Sciences, USA). Pengaruh perlakuan yang berbeda nyata diuji lanjut dengan uji selang berganda Duncan (DMRT) pada taraf nyata $5 \%$.

\section{HASIL DAN PEMBAHASAN}

\section{Karakteristik Hasil Fermentasi Limbah Jagung}

Perlakuan fermentasi dengan ukuran cacahan bahan organik dari limbah jagung yang berbeda untuk mengetahui proses fermentasi paling efektif dan efisien. Berdasarkan data yang diperoleh, ukuran cacahan berpengaruh terhadap proses fermentasi (Devi et. al., 2017; Indriani, 2002). Semakin kecil ukuran bahan organik yang difermentasi menunjukkan semakin cepat proses fermentasi. Hal ini ditandai dengan karakter hasil fermentasi yaitu suhu sudah tidak panas, kadar air rendah, kelembaban rendah, warna coklat gelap, dan aroma sudah tidak menyengat (Tabel 1). Hal ini sama dengan yang dikemukakan oleh Murbandono (2010) yang menyatakan bahwa kompos yang baik memiliki ciri berwarna coklat tua hingga hitam, suhunya sama dengan suuhu ruangan, berbentuk remah, dan tidak berbau. 
Tabel 1 Perbedaan karakter pupuk organik limbah jagung dengan ukuran cacahan berbeda setelah 3 minggu fermentasi

\begin{tabular}{|c|c|c|c|c|c|}
\hline \multirow[t]{2}{*}{ Perlakuan } & \multicolumn{5}{|c|}{ Karakter } \\
\hline & Suhu & Kadar air & RH & Warna & Aroma \\
\hline S1 & $32.7^{\circ} \mathrm{C}$ & $15 \%$ & $70 \%$ & Coklat gelap & Agak asam dan agak bau tanah \\
\hline S2 & $34.2^{\circ} \mathrm{C}$ & $15 \%$ & $72 \%$ & $\begin{array}{l}\text { Coklat agak } \\
\text { gelap }\end{array}$ & Agak asam menyengatdan agak bau tanah \\
\hline S3 & $36.1^{\circ} \mathrm{C}$ & $21 \%$ & $78 \%$ & Coklat & Asam menyengat \\
\hline S4 & $37.2^{\circ} \mathrm{C}$ & $19 \%$ & $77 \%$ & Coklat & Asam menyengat \\
\hline
\end{tabular}

Tabel 2. Pengaruh berbagai hasil fermentasi pupuk organik limbah jagung terhadap perkecambahan benih jagung ungu

\begin{tabular}{lcc}
\hline Perlakuan & Rata-rata benih berkecambah $^{1}$ & Rata-rata persentase daya kecambah benih jagung ungu (\%) \\
\hline S1 & $24.3 / 25$ & 97.2 \\
S2 & $23.7 / 25$ & 94.8 \\
S3 & $23.7 / 25$ & 94.8 \\
S4 & $24.3 / 25$ & 97.2 \\
Kontrol & $23.7 / 25$ & 94.8 \\
\hline
\end{tabular}

${ }^{\mathrm{T}}$ unit pengamatan dalam perlakuan ini adalah 25 benih jagung ungu

Tabel 3. Pengaruh berbagai hasil fermentasi pupuk organik limbah jagung terhadap pertumbuhan jagung ungu

\begin{tabular}{lcccccc}
\hline & \multicolumn{5}{c}{ Tinggi tanaman pada- HST $(\mathrm{cm}){ }^{1}$} \\
\cline { 2 - 7 } & 14 & 28 & 42 & 56 & 70 \\
\hline S1 & $14.0 \mathrm{c}$ & $27.0 \mathrm{a}$ & $55.7 \mathrm{e}$ & $84.3 \mathrm{~d}$ & $109.7 \mathrm{c}$ & $129.0 \mathrm{c}$ \\
S2 & $11.7 \mathrm{ab}$ & $33.0 \mathrm{c}$ & $50.7 \mathrm{~d}$ & $82.0 \mathrm{c}$ & $107.0 \mathrm{~b}$ & $126.0 \mathrm{~b}$ \\
S3 & $11.7 \mathrm{ab}$ & $31.0 \mathrm{bc}$ & $47.0 \mathrm{bc}$ & $79.0 \mathrm{ab}$ & $105.7 \mathrm{a}$ & $125.7 \mathrm{ab}$ \\
S4 & $10.0 \mathrm{a}$ & $30.3 \mathrm{ab}$ & $43.0 \mathrm{ab}$ & $77.7 \mathrm{a}$ & $106.0 \mathrm{ab}$ & $125.0 \mathrm{ab}$ \\
Kontrol & $10.0 \mathrm{a}$ & $27.7 \mathrm{a}$ & $42.7 \mathrm{a}$ & $78.3 \mathrm{a}$ & $105.3 \mathrm{a}$ & $124.3 \mathrm{a}$ \\
\hline
\end{tabular}

${ }^{\mathrm{T}}$ Angka pada kolom yang sama yang diikuti huruf yang sama tidak berbeda nyata pada $\mathrm{P}=0.05$

Pengaruh pupuk organik terhadap daya kecambah benih. Pemberian pupuk organik dalam budidaya termasuk budidaya jagung ungu memberikan efek untuk memperbaiki tekstur tanah. Tekstur tanah ini menjadi hal penting dalam proses germinasi. Benih jagung termasuk dalam kelompok monokotil yan berarti bahwa biji tertinggal di tanah dan hanya tunas yang tumbuh ke atas. Kondisi media tanam tersebut sangat mempengaruhi keberhasilan perkecambahan jagung. Berdasarkan data yan diperoleh, secara umm menunjukkan bahwa perkecambahan benih jagung ungu pada semua perlakuan hampir sama dan tidak ada pengaruh yang berbeda. Persentase perkecambahan berkisar antara $94.8 \%$ hingga $97.2 \%$. Perkecambahan tertinggi terdapat pada perlakuan S1 dan S4 (Tabel 2). Secara umum, kelima perlakuan tidak menunjukkan pengaruh yang berbeda. Selain itu, kompos yang dihasilkan pada masing-masing perlakuan tidak bersifat toksik.

Pengaruh perlakuaan terhadap Pertumbuhan tanaman. Pengamatan pertumbuhan tanaman dilakukan dengan cara mengukur tinggi tanaman. Pengukuran tinggi tanaman dilakukan pada 14 hst, 28 hst, 42 hst. Hingga pengamatan terakhir, yakni $42 \mathrm{HST}$, diperoleh data pertumbuhan yang bervariasi. Pada 14 HST, 42, 56, 70, 84. HST perlakuan terbaik ditunjukkan oleh S1 atau perlakuan dengan bahan organik cacahan terkecil dan waktu fermentasi 3 minggu. Adapun data lengkap dari pengukuran pertumbuhan tanaman jagung ungu disajikan pada Tabel 3 . Pengaruh kompos terhadap pertumbuhan jagung ungu dapat dipengaruhi kandungan hara dalam kompos perlakuan. Kualitas kompos identik dengan kandungan hara didalamnya (Novitamala et. al., 2015).

Pengaruh perlakuaan terhadap kandungan klorofil daun. Kandungan klorofil digunakan sebagai salah satu parameter karena sebagai indikator yang menunjukkan tanaman sehat atau tidak. Kandungan klorofil ini sangat dipengaruhi oleh faktor lingkungan seperti sinar matahari, karbohidrat, oksigen, nitrogen, magnesium, besi, air, dan temperatur (Agustamina et. al., 2016). Hal ini dapat digunakan untuk melihat respon tanaman terhadap pupuk organik yang diberikan dengan asumsi kandungan unsur hara pada tiap-tiap pupuk organik. Berdasarkan data yang diperoleh menunjukkan bahwa kandungan klorofil tertinggi pada daun jagung umur 3-minggu adalah pada perlakuan S1 (Tabel 4). Hal tersebut dapat disebabkan karena S1T3 kemungkinan besar pupuk organik hasil fermentasi sudah matang sempurna dan memiliki kandungan hara yang siap diserap tanaman. 
Tabel 4. Pengaruh perlakuan terhadap kandungan klorofil daun

\begin{tabular}{lc}
\hline Perlakuan & Kandungan klorofil \\
\hline S1 & $21.3 \mathrm{c}$ \\
S2 & $20.5 \mathrm{ab}$ \\
S3 & $20.4 \mathrm{a}$ \\
S4 & $20.7 \mathrm{bc}$ \\
Kontrol & $20.4 \mathrm{a}$ \\
\hline
\end{tabular}

Tabel 5. Pengaruh berbagai hasil fermentasi pupuk organik limbah jagung terhadap umur berbunga, ukuran tongkol, bobot tongkol, dan bobot per 1000 biji

\begin{tabular}{lcccc}
\hline \multirow{2}{*}{ Perlakuan } & \multicolumn{3}{c}{ Pengaruh perlakuan } \\
\cline { 2 - 5 } & $\begin{array}{c}\text { Umur berbunga } \\
(\text { HST })\end{array}$ & $\begin{array}{c}\text { Ukuran Tongkol } \\
(\mathrm{cm})\end{array}$ & Bobot tongkol $(\mathrm{g})$ & Bobot per 1000 biji (g) \\
\hline S1T3 & 63.7 & $15.5 \mathrm{~d}$ & $166.0 \mathrm{~d}$ & $311.3 \mathrm{~d}$ \\
S2T3 & 61.3 & $14.9 \mathrm{c}$ & $136.0 \mathrm{ab}$ & $303.3 \mathrm{bc}$ \\
S3T3 & 63.7 & $15.1 \mathrm{~cd}$ & $160.3 \mathrm{~cd}$ & $303.3 \mathrm{bc}$ \\
S4T3 & 62.0 & $13.2 \mathrm{ab}$ & $126.0 \mathrm{a}$ & $302.7 \mathrm{ab}$ \\
Kontrol & 62.0 & $13.1 \mathrm{a}$ & $125.8 \mathrm{a}$ & $302.3 \mathrm{a}$ \\
\hline
\end{tabular}

${ }^{1}$ Angka pada kolom yang sama yang diikuti huruf yang sama tidak berbeda nyata pada $\mathrm{P}=0.05$

Pengaruh perlakuaan terhadap umur berbunga, ukuran tongkol, bobot tongkol, dan bobot per 1000 biji. Parameter umur berbunga, ukuran tongkol, bobot tongkol, dan bobot per 1000 biji ini digunakan untuk melihat respon tanaman pada fase generatif terhadap pupuk organik yang diberikan. Hasil pengamatan menunjukkan umur berbunga tanaman pada tiap-tiap perlakuan tidak berbeda nyara yakni berkisar 60-64 hari. Sementara tongkol jagung terbesar, bobot tongkol dan bobot per 1000 biji tertinggi diperoleh dari tanaman dengan perlakuan S1 (Tabel 5). Hal ini dapat disebabkan karena pertumbuhan optimum pada fase generatif pada perlakuan S1. Selain itu dapat disebabkan karena kandungan N, P, K dalam kompos hasil fermentasi yang diberikan berbeda-beda. Menurut Nurdin et. al., (2009) melaporkan bahwa tanaman jgung yang tidak diberikan N, P, $\mathrm{K}$ memiliki umur berbunga yang lebih panjang.

\section{KESIMPULAN}

Ukuran cacahan berpengaruh terhadap proses fermentasi. Semakin kecil ukuran cacahan limbah jagung semakin cepat proses fermentasi. Hasil fermentasi dari masing-masing perlakuan berpengaruh terhadap pertumbuhan dan perkembangan tanaman, serta kandungan klorofil tanaman jagung ungu. Perlakuan terbaik ditunjukkan oleh perlakuan $\mathrm{S} 1$ yang menunjukkan respon perkecambahan dan pertumbuhan paling tinggi, kandungan klorofil tinggi, umur berbunga pendek, serta memiliki bobot tongkol dan biji tertinggi dibandingkan dengan perlakuan yang lain.

\section{DAFTAR PUSTAKA}

[BPS]. 2015. Produktivitas Jagung Jawa Timur. http://Jatim.bps.go.id/ tgl 23 juni 2018.
[BPS]. 2016. Produktivitas Jagung Nasional. http://bps.go.id/tgl 24 juni 2018.

[Litbang Pertanian]. 2018. Teknologi budidaya jagung. Tersedia pada: sulbar.litbang.pertanian.go.id/ind/images/.../TEKNO LOGI-BUDIDAYA-JAGUNG.pdf. tanggal akses 28 juni 2018.

Agustamia, C., A. Widiastuti, C. Sumardiyono. 2016. Pengaruh stomata dan klorofil pada ketahanan beberapa varietas jagung terhadap penyakit bulai. Jurnal Perlindungan Tanaman Indonesia. 20(2):89-94

Devi, V., V.J.H. Sumathy. 2017. Production of biofertilizer from fruit waste. European journal of pharmaceutical and medical research, 4(9):436-443

Indriani, Y.H. 2002. Membuat Kompos Secara kilat. Jakarta (ID): Penebar Swadaya.

Novitamala, C.B., B. Suwerda, I. Werdiningsih. 2015. Efektivitas berbagai dosis bio-slurry sebagai bumbu kompos terhadap waktu pembentukan dan kualitas kompos di Dusun Gadingharjo, Donotirto, Kretek, Bantul. Sanitasi, Jurnal Kesehatan Lingkungan. 7(2):51-58.

Nurdin, P.M., Z. Ilahude, F. Zakaria. 2009. Pertumbuhan dan hasil jagung yang dipupuk $\mathrm{N}$, P, dan $\mathrm{K}$ pada tanah Vertisol Isimu Utara Kabupaten Gorontalo. Jurnal Tanah Tropika, 14(1): 49-56. 
Suarni, H. Subagio. 2013. Potensi Pengembangan Jagung dan Sorgum Sebagai Sumber Pangan Fungsional. Jurnal Litbang Pertanian. 32(2):47-55.

Suarni, S., M. Yasin. 2015. Jagung sebagai sumber pangan fungsional. Iptek Tanaman Pangan. 6(1).
Suarni, M. Yasin. 2011. Jagung sebagai sumber pangan fungsional. Iptek Tanaman Pangan, 6(1):41-56.

Tangendjaya, B., E. Wina. 2007. Limbah tanaman dan produk samping industri jagung untuk pakan. Bagian Buku Jagung. Puslitbang Tanaman Pangan. Hal. 427455 . 